\title{
The Impact of Extracorporeal Shock Wave Therapy and Dry Needling Combination on the Pain, Grip Strength and Functionality in Patients Diagnosed with Lateral Epicondylitis
}

\author{
Lateral Epikondilit Tanılı Hastalarda Ekstrakorporeal Şok Dalga Tedavisi ve Kuru Iğneleme \\ Tedavisi Kombinasyonunun Ağrı, Kavrama Gücü ve Fonksiyonellik Üzerine Etkisi \\ (D) Fatih Bağcıer, (D) Nurdan Yılmaz* \\ Kars Harakani State Hospital, Clinic of Physical Medicine and Rehabilitation, Kars, Turkey \\ *Gaziosmanpasa University Faculty of Medicine, Department of Physical Medicine and Rehabilitation, Tokat, Turkey
}

\section{Abstract}

Objective: The aim of this study was to investigate the effects of extracorporeal shock wave therapy (ESWT) and dry needling (DN) combination to the trigger points in the forearm extensor muscles on pain, grip strength and functionality in patients diagnosed with lateral epicondylitis.

Materials and Methods: Forty patients who were clinically diagnosed with lateral epicondylitis were included in the study. The patients were divided into two groups as ESWT and ESWT + DN. Patients in the ESWT and exercise group were applied 2.000 pulses, once a week, three sessions; in addition to that three sessions of DN therapy was applied to the other group. Also, stretching and eccentric strengthening exercises were applied to the patients in both groups. The pain severity of the patients which occured with palpation and grip was measured by Visual Analog Scale (VAS), lateral epicondyle sensitivity by an algometer, grip strength by dynamometer and functionality level by the patient-rated tennis elbow evaluation (PRTEE) pre-treatment and at the end of treatment (first month).

Results: In both groups; there were statistically significant improvements in first month VAS scores of the pre- and post-treatment (morning, activity, and rest) $(p<0.001)$; in the comparison of the intergroup, the improvement in pain scores, except for night pain, was found to be superior in the ESWT + DN group $(p<0.001)$. The evaluation of the most sensitive region of the lateral epicondylitis pre- and post-treatment with algometer were compared, there was a significant improvement in both groups $(p<0.001)$, whereas the improvement in ESWT + DN group was observed to be superior $(p<0.001)$. While the maximum grip strength values measured in the elbow flexion and extension position increased significantly in both groups after the treatment, the increase in the extension position in the ESWT + DN group was outstanding $(p<0.05)$. When the pre- and post-treatment changes seen in the PRTEE scale of the patients were examined; a statistically significant decrease was observed in all groups in favor of improvement post-treatment $(p<0.05)$. In ESWT + DN group, pain score and function score change were more effective than ESWT group $(p<0.001)$.

Conclusion: These results suggest that ESWT and DN combination therapy in lateral epicondylitis provide better clinical outcomes than ESWT treatment alone.

Keywords: Lateral epicondylitis, dry needling, extracorporeal shock wave therapy

\section{Öz}

Amaç: Bu çalışmada, lateral epikondilit tanılı hastalarda, ekstrakorporeal şok dalga tedavisi (ESWT) ile ön kol ekstansör kaslarındaki aktif tetik noktalara kuru iğneleme (DN) tedavisi kombinasyonunun ağrı, kavrama kuvveti ve fonksiyonellik üzerine etkisi araştırıldı.

Gereç ve Yöntemler: Çalışma 40 hasta üzerinde gerçekleştirildi. Hastalar; ESWT ve ESWT + DN olmak üzere iki gruba ayrıldı. ESWT ve egzersiz grubundaki hastalara 2000 atım, haftada bir kere, 3 seans; diğer gruba ise buna ek olarak 3 seans DN tedavisi uygulandı. Her iki gruptaki hastalara germe ve eksentrik kuvvetlendirme egzersizleri verildi. Hastaların palpasyon ve kavrama ile meydana gelen ağrı şiddeti Vizuel Ağrı Skalası (VAS) ile, lateral epikondil hassasiyeti algometre ile, kavrama kuvveti dinamometre ile ve fonksiyonellik düzeyi ise hasta bazlı önkol değerlendirme anketi (PRTEE) ile tedavi öncesinde, tedavi bitiminde (1. ay) değerlendirildi.

Bulgular: Tedavi öncesi ve tedavi sonrası 1. ay sabah, aktivite ve istirahat VAS ağıı skorları karşılaştırılığında; her iki grupta da bütün VAS değerleri istatistiksel olarak anlamlı iken $(p<0,001)$, gruplar arası kıyaslama yapıldığında ESWT + DN grubunda ağrı skorlarında düzelmenin gece

Address for Correspondence/Yazıșma Adresi: Fatih Bağcıer MD, Kars Harakani State Hospital, Clinic of Physical Medicine and Rehabilitation, Kars, Turkey Phone: +90 5442429042 E-mail: bagcier_42@hotmail.com ORCID ID: orcid.org/0000-0002-6103-7873 Received/Geliş Tarihi: 13.02.2019 Accepted/Kabul Tarihi: 09.04.2019 
ağrısı hariç daha üstün olduğu görülmüştür $(p<0,001)$. Tedavi öncesi ve tedavi sonrası lateral epikondilin en hassas bölgesinin algometre ile değerlendirilmesi kıyaslandığında her iki grupta da anlamlı bir düzelme görülürken ( $p<0,001)$, ESWT + DN grubunda düzelmenin üstün olduğu gözlemlenmiştir ( $p<0,001)$. Dirsek fleksiyon ve ekstansiyon pozisyonunda ölçülen maksimum kavrama kuvveti değerleri tedavi sonrasında her iki grupta da anlamlı artarken ESWT + DN grubunda ekstansiyon pozisyonundaki artış daha üstündü $(p<0,05)$. Hastaların tedavi öncesi ve tedavi sonrası PRTEE skalasında görülen değişimler incelendiğinde; tedavi sonrasında bütün gruplarda tedavi öncesine göre iyileşme lehine istatistiksel olarak anlamlı azalma görüldü $(p<0,05)$. ESWT ile ESWT + DN grupları birbirleriyle karşılaştııılığında; ESWT + DN grubunda ağrı skoru, fonksiyon skoru değişiminin ESWT grubuna göre daha etkili olduğu görüldü $(p<0,001)$.

Sonuç: Çalışmamız, lateral epikondilit tedavisinde ESWT ve DN kombinasyon tedavisinin sadece ESWT tedavisinden daha iyi klinik sonuçları olduğunu göstermiştir.

Anahtar kelimeler: Lateral epikondilit, kuru iğneleme, ekstrakorporeal şok dalga tedavisi

\section{Introduction}

Lateral epicondylitis (LE) is the tendinopathy leading to pain in the musculotendinous junction of lateral epicondyle and wrist extensor muscles (1). It usually occurs between the ages of 35-50 (2). It is caused by overloading and repetitive movements requiring wrist extension. With repeating and overloading, tissue damage occurs by exceeding the strength, flexibility and endurance tolerance of the tissue (3). As repetitive tissue damage continues, pain, strength and functional loss due to degeneration progress. Extensor carpi radialis brevis (ECRB) muscle in particular, extensor carpi radialis longus (ECRL), extensor digitorum communis (EDC) and brachioradialis (BR) muscles tend to be affected. In the treatment of $L E$; there are conservative, medical or surgical approaches to reduce pain and improve function. Researchers reported that conservative and medical treatments were effective in acute stages and surgery was effective in advanced calcified stages (4). The aim of conservative treatment is; to reduce pain, to control the tendon-bearing loads, to restore flexibility and strength, and to prevent recurrence of symptoms. In conservative approaches, ultrasound, iontophoresis, orthosis, laser, manipulation, mobilization, dry needling (DN) and exercise methods are frequently used. Chard and Hazleman (5) has stated that they used more than 40 treatment methods for LE. However, there is insufficient evidence for the efficacy of treatment modalities due to methodological differences between studies (6). In the literature, the effectiveness of exercise is prominent (7). Although extracorporeal shock wave therapy (ESWT) has been used frequently in recent years, its effect is still controversial (1). ESWT is a treatment modality for the application of highintensity sound waves to the body. Shock waves are caused by sudden changes in pressure. These changes create strong waves that cause compression and tension (8). The success rate of treatment varies between $65 \%$ to $91 \%$ (9). DN is a relatively new the treatment for LE and studies have been conducted in the literature $(10,11)$. DN is a minimally invasive method which is known to stimulate myofascial trigger points (MTrPs) in muscle tissue, cause biochemical changes in MTrPs' microenvironment and reduce the spontaneous electrical activity of the trigger points $(12,13)$. Fernandez-Carnero (14) described pain patterns of active MTrPs in the ECRB, ECRL, BR, EDC muscles, which were similar to the pain caused by LE. In our study, we aimed to evaluate the effect of adding DN treatment to ECRB, ECRL, EDC and BR muscles active MTrPs in addition to ESWT treatment to lateral epicondyle.

\section{Materials and Methods}

Forty patients ages between 18-70 who were admitted to Kars Harakani State Hospital, Clinic of Physical Medicine and Rehabilitation Outpatient with the complaint of elbow pain between May 2018 and August 2018 were included in the study. All participants were informed about the study and their written informed consent was taken. The approval of the Ethics Committee of the Kars Kafkas University Faculty of Medicine was obtained for our study (18/05/2018, LUT 10/12-13).

The inclusion criteria of our study included patients who had symptoms for at least 6 weeks between the ages of 18-70 and who did not receive any anti-inflammatory treatment during the treatment period and who were diagnosed with LE (15). Along with physical examination, other possible differential diagnoses were excluded by using appropriate laboratory tests and radiological methods. Direct X-rays of the elbow were obtained to rule out radio-humeral joint arthritis, osteochondritis dissecans, or osteonecrosis. Patients with cervical radiculopathy or posterior interosseous nerve entrapment were excluded from the study.

The level of education level (primary school and above) is determined as to be able to understand and complete the treatment, interventions and forms to be used in the evaluation. Malignancy, presence of active infection, history of diffuse inflammatory rheumatic disease, trauma in the elbow area, skin lesion, infection or presence of open wounds, neuropathy, radiculopathy, peripheral circulatory disorder, coagulopathy, use of warfarin, arthropathy, presence of congenital or acquired upper extremity deformity, the presence of fracture sequelae, prosthesis, the presence of internal plate screw fixator, cardiac pacemaker, metal implant in the region of application and the presence of conditions which may be inconvenient in the application of physiotherapy such as pregnancy were not included in the study.

The patients were divided into two equal groups of 20 according to the randomization method. 


\section{The Following Parameters Were Used in the Evaluations:}

1. Socio-demographic and clinical characteristics of patients

2. Subjective pain intensity

3. Evaluation of pain with algometer

4. Evaluation of grip strength with Jamar Hand dynamometer

5. Evaluation of functionality: Patient rated forearm evaluation questionnaire (PRTEE-T).

Evaluations were performed twice as before and one month after treatment.

Evaluation of Grip Strength: Grip is an indicator of general muscle strength. The wrist extensor muscles provide stabilization during grip and other hand functions. During the grip, the ECRL and ECRB muscles contract more flexibly against the flexor moment created by the wrist and finger flexor muscles (16). Patients' normal range of motion were evaluated before comparison of grip strength and compared with the intact side. Grip force was evaluated with Jamar Hand Dynamometer. Due to the change in muscle tension in different elbow positions of the ECRB muscle, the elbow was evaluated in two different positions as extension and $90^{\circ}$ flexion.

Evaluation of Functionality: The functionality of the patients was evaluated with PRTEE-T before and after treatment. PRTEE-T consists of 15 questions that question the pain experienced by the patients during the week before. The first 5 questions include pain level and the other 10 questions include elbow related functions. In the functionality section; 6 questions include special activities and 4 questions include daily activities. The total score ranges from 0 to 100 and high scores show increased pain and loss of functionality (17).

\section{Physiotherapy and Rehabilitation Program}

Group 1: Cold application - home exercise program - ESWT treatment (3 sessions with 1 week intervals).

Group 2: Cold application - home exercise program - ESWT treatment + DN treatment (3 sessions with 1 week intervals)

All evaluations were applied to two groups both before treatment and one month after treatment.

Treatments applied to patients;

1. Cold Application: At the beginning of each treatment, the gel ice packs were wrapped with a damp towel and applied around the elbow joint for 15 minutes.

2. Home Exercise Program: A home exercise program consisting of eccentric strengthening and stretching exercises planned to increase patients' resistance every week. Patients; strength training exercises for wrist extensors and forearm supination were taught and home exercise program was started with 3 sets of 10 repeats per day.

For wrist extensors, wrist flexion was performed with a count to 20 when the wrist was in full extension position and then passively returned to the starting position with the other hand. Starting from the $5^{\text {th }}$ session of the treatment, the eccentric strength training for the wrist extensors was continued with the red-coloured resistant band and the eccentric strength training for the forearm supination was added to the exercise program. Eccentric supination training for the forearm was started weightless. The training program was then continued with a red-coloured resistant band. The patients who participated in the treatment were asked about the presence and/or increase of pain due to exercise before each treatment session. In the event of severe pain during exercise, patients were informed about interrupting the exercise.

In addition to strengthening exercises; stretching exercises for the affected-side wrist extensor muscles were taught. Patients were asked to stretch for 20 seconds with the other hand in the internal rotation, elbow extension, forearm pronation, wrist flexion and ulnar deviation positions. Stretching exercises were recommended to be performed before reinforcement exercise by giving 3 sets a day, 5 to 20 seconds in a set and 45 seconds rest in the first week. From the $2^{\text {nd }}$ week of treatment, 5 sets of 5 to 20 seconds per day before the exercise were asked to be performed 5 to 20 seconds after the exercise (18). The pain increase of the patients was questioned before each treatment. 3. ESWT Application: For the patients randomized into two groups; ESWT was applied once per week with $15 \mathrm{~Hz}$ frequency settings in the form of a 2 bar and 2000 pulse. ESWT was applied with equal shares of 2000 pulse to three points that are precisely determined in $\mathrm{LE}$; to the most swollen part of the ECRB muscle with $1 \mathrm{~cm}$ above and $1 \mathrm{~cm}$ below the posterior epicondyle (19). Painful points of the patients were determined by palpation. After ESWT treatment, cold application was performed for 15 minutes.

4. Dry Needling: Active MTrPs in ECRB, ECRL, EDC, BR muscles were treated with DN. An assessor blind to the participants' condition evaluated the muscles manually for the presence of active or latent trigger points. The compression pain at the trigger points within the muscle was accepted as active MTrP in the form of pain reflected in the lateral epicondyle region. Only the trigger points localized with palpation were evaluated as latent. Dry neeedling was applied according to the localization reference

\section{Table 1. Patients' characteristics in pretreatment visit}

Age (year)

Height $(\mathrm{cm})$

Weight $(\mathrm{kg})$

$\operatorname{BMI}\left(\mathrm{kg} / \mathrm{m}^{2}\right)$

Disease duration (month)

\begin{tabular}{|l|l|l|}
\hline Group 1 (ESWT) & Group 2 (ESWT + DN) & $\mathbf{p}$ \\
\hline $428.5 \pm 12.98$ & $39.65 \pm 14.08$ & 0.459 \\
$164.75 \pm 9.45$ & $171.65 \pm 10.5$ & 0.161 \\
$70.05 \pm 9.88$ & $75.2 \pm 12.73$ & 0.035 \\
$29.73 \pm 5.34$ & $28.15 \pm 6.97$ & 0.418 \\
$4.15 \pm 2.39$ & $4.95 \pm 1.39$ & 0.204
\end{tabular}

ESWT: Extracorporeal shock wave therapy, DN: Dry needling, BMI: Body mass index

Values average was given as \pm standard deviation. Independent samples t-test was used 
of MTrPs in ECRB, ECRL, EDC, BR muscles by Simons et al. (20). The practitioner was an expert with 5 years of experience in this field. The patient was placed in supine position during the procedure. The needle was modulated by pulling inside the MTrP, until the local twitch response was obtained. If the patient felt a serious discomfort, the practice was interrupted. Seirin brand $0.6 * 30 \mathrm{~mm}$ acupuncture needles were used during application.

\section{Statistical Analysis}

Data analysis was performed by using SPSS for Windows 19.0 software program. Descriptive statistics were given as number, percent, median, mean and standard deviation. The Kolmogorov-Smirnov test was used for data normality. The results were compared within the groups themselves and between the groups. In these comparisons, repeated measures ANOVA and Bonferroni correction for multiple comparisons were used. A level of significance of $p<0.05$ was accepted.

\section{Results}

The socio-demographic and clinical features of the patients were summarized in Table 1. Before treatment and 1 month after the treatment; morning, activity and rest Visual Analog Scale (VAS) pain scores were compared; while all VAS values were statistically significant in both groups $(p<0.001)$, it was seen that the improvement in pain scores in the ESWT + DN group was superior $(p<0.001)$ except night pain (Table 2$)$. When the most sensitive region of LE was compared with the algometer before treatment and after the treatment, a significant improvement was observed in both groups $(p<0.001)$, while improvement in ESWT + DN group was superior $(p<0.001)$ (Table 2$)$. The maximum grip strength values measured in the elbow flexion and extension position increased significantly in both groups after the treatment, whereas the increase in the extension position in the ESWT + DN group was superior $(p<0.05)$ (Table 3).

Table 3 shows the changes in the PRTEE scale within the group before and one month after treatment. When the changes in the PRTEE scale before and after treatment were examined; a statistically significant decrease was observed in favour of improvement in all groups after treatment $(p<0.05)$ (Table 3$)$. In ESWT + DN group, pain scores, function scores changes were more effective than the only ESWT group $(p<0.001)$ (Table 3$)$.

\section{Discussion}

Although many medical and conservative methods are used for $L E$, there is no consensus on the efficacy of these treatments (21). On the other hand, in recent studies, multimodal approaches are seen in the treatment of $\operatorname{LE}(22,23)$. This study showed that ESWT + DN combination therapy in the treatment of $L E$, grip strength and functionality were effective for early pain reduction. Although the etiology of LE is unknown, overuse and micro traumas affect disease formation (24). ESWT, one of the most common conservative approaches, is thought to stimulate the nerve endings in painful points caused by reflex pain inhibition (hyper-stimulation analgesia). In addition, energy transfer and the local trauma of the ECRB tendon, acute inflammation and repairment process initiated by increased secreted angiogenesis-related growth factors, formation of new vessels and oxygenation are the other mechanisms $(25,26)$. In studies performed with ESWT, a comparison was usually made with the placebo-controlled group. Exercise therapy, which is an effective treatment for LE, has been used in conjunction with ESWT (27).

Simons et al. (20) described pain patterns of active MTrPs in the anterior limb extensor muscles, which may cause pain in

\section{Table 2. Visual Analog Scale and pressure pain threshold scores at pre-posttreatment visit}

\begin{tabular}{|l|l|l|l|}
\hline & Group 1 (ESWT) & Group 2 (ESWT + DN) & $\mathbf{p}_{\mathbf{1}}$ \\
\hline Night VAS-1 & $5.3 \pm 4.23$ & $7.5 \pm 2.84$ & 0.061 \\
\hline Night VAS-2 & $2.6 \pm 2.09$ & $2 \pm 0.86$ & 0.242 \\
\hline & $<0.001$ & $<\mathbf{0 . 0 0 1}$ & - \\
\hline Activity VAS-1 & $8.75 \pm 1.37$ & $8.15 \pm 0.81$ & 0.101 \\
\hline Activity VAS-2 & $3.8 \pm 1.11$ & $2.15 \pm 0.59$ & $<\mathbf{0 0 1}$ \\
\hline $\mathbf{p}_{\mathbf{2}}$ & $<0.001$ & $<\mathbf{0 . 0 0 1}$ & - \\
\hline Rest VAS-1 & $7.8 \pm 1.54$ & $8.05 \pm 1.15$ & 0.564 \\
\hline Rest VAS-2 & $3.25 \pm 1.16$ & $2.1 \pm 0.55$ & $<\mathbf{0 1}$ \\
\hline $\mathbf{p}_{\mathbf{2}}$ & $<\mathbf{0 . 0 0 1}$ & $<\mathbf{0 . 0 0 1}$ & - \\
\hline PPT-1 & $12.45 \pm 3.78$ & $11.9 \pm 2$ & 0.568 \\
\hline PPT-2 & $19.7 \pm 4.12$ & $25.65 \pm 4.97$ & $<\mathbf{0 0 1}$ \\
\hline $\mathbf{p}_{\mathbf{2}}$ & $<0.001$ & $<\mathbf{0 . 0 0 1}$ & - \\
\hline
\end{tabular}

ESWT: Extracorporeal shock wave therapy, DN: Dry needling, VAS: Visual Analog Scale, PPT: Pressure pain threshold, $p_{1}$ : Within-subject comparison, $p_{2}$ : Between-subject comparison

A repeated measure ANOVA was used 
lateral epicondyle region. Therefore, we think that MTrPs are important in the treatment of LE. In this study, we investigated the effect of ESWT and DN combination on pain parameters, grip strength and functionality and aimed to contribute to the literature with this combination therapy which has not been performed before.

Shmushkevich et al. (28) suggested that myofascial pain also plays a role in the pathogenesis of the disease. In their study, they evaluated the presence of active or latent trigger points in the ECRB, ECRL, EDC, BR muscles in twenty healthy controls with treatment-resistant twenty patients with LE. They showed significant difference in active MTRPs number in the patient group (28). In an other study by Fernandez-Carnero et al. (29), 25 patients with unilateral chronic LE and active and latent MTRPs in 20 healthy populations, active MTRPs rates in the LE group were $100 \%$ in ECRB, $96 \%$ in ECRL, $76 \%$ in EDC and $32 \%$ in BR. Interestingly, a significantly greater number of latent MTrPs were found in the forearm muscles of the unaffected side compared to the control group (29).

Stenhouse et al. (10) compared DN + platelet rich plasma (PRP) combinations with DN treatment in treatment-resistant patients. In a similar study comparing PRP and DN therapies, by Mishra and Pavelko (30) showed that PRP treatment had no superiority to DN treatment. In both of the studies, a thick needle was used in the DN technique, and the needling was directly applied to the painful points in the lateral epicondyle region with the peppering technique $(10,30)$. In another LE study, Uygur et al. (11) compared the combination of DN treatment and medical therapy + brace. In this study; a thinner acupuncture needle was applied to the painful area of lateral epicondyle, DN treatment showed superiority in both pain and PRTEE scores. Uygur et al. (11) treated the most painful area is marked at the lateral epicondyle, DN is performed with DN. In the literature, there are randomized controlled trials in which only MTrPs of ECRB, ECRL, EDC, BR muscles are targeted in the treatment of LE. From these studies Ajimsha et al. (31) examined the effects of myofascial release and sham ultrasound treatment on pain and functionality in patients with chronic LE. In the study of Nourbakhsh and Fearon (32), manual osteopathic technique was used for 23 patients with chronic LE and MTrPs were targeted in one of the groups, while in the other group parts adjacent to MTrPs was treated. It was shown that improvement in pain and functionality scores was superior in the group in which MTrPs were targeted. Therefore, the treatment of active MTrPs of ECRB, ECRL, EDC, BR muscles in the treatment of LE was found to be effective both in reducing pain and increasing the daily activities of the patient (28). In mentioned studies; while treating MTrPs; cold application and/ or home exercises programs for tendinitis were not added to the treatment. We think that the treatment combinations for both active MTrPs and tendinitis will be more effective. In our study, this situation was taken into consideration and on the one hand, tendinitis was treated with ESWT, ice application and exercise therapy; on the other hand, active MTRPs in the $E C R B, E C R L, E D C, B R$ muscles of patients were treated with $D N$. The active MTRPs' DN in the ECRB, ECRL, EDC, BR muscles improved the patient's adaptation to exercise by decreasing the pain felt during stretching exercises and increased the flexibility of the muscles.

Pain is the most important problem in patients with LE. There were statistically significant changes in VAS scores in the ESWT

\section{Table 3. Functional assessment at pre-posttreatment visit}

\begin{tabular}{|c|c|c|c|}
\hline & Group 1 (ESWT) & Group $2($ ESWT + DN) & $p_{1}$ \\
\hline $\mathrm{FLX}-1$ & $16.00 \pm 7.53$ & $15.65 \pm 4.07$ & 0.856 \\
\hline $\mathrm{FLX}-2$ & $29 \pm 9.04$ & $33.95 \pm 6.86$ & 0.058 \\
\hline$p_{2}$ & $<0.001$ & $<0.001$ & - \\
\hline EXT-1 & $16.9 \pm 7.02$ & $15.35 \pm 4.23$ & 0.403 \\
\hline EXT-2 & $28.35 \pm 10.12$ & $34.25 \pm 7.5$ & 0.043 \\
\hline$p_{2}$ & $<0.001$ & $<0.001$ & - \\
\hline PRTEE VAS-1 & $32.75 \pm 5.88$ & $33.95 \pm 6.11$ & 0.531 \\
\hline PRTEE VAS-2 & $20.95 \pm 5.32$ & $18.5 \pm 5.23$ & 0.150 \\
\hline$p_{2}$ & $<0.001$ & $<0.001$ & - \\
\hline PRTEE FUNC-1 & $60.15 \pm 11.68$ & $62.05 \pm 11.4$ & 0.606 \\
\hline PRTEE FUNC-2 & $38.55 \pm 5.35$ & $33.75 \pm 6.54$ & 0.015 \\
\hline$p_{2}$ & $<0.001$ & $<0.001$ & - \\
\hline PRTEE TOTAL-1 & $93.2 \pm 17.02$ & $96.1 \pm 17.23$ & 0.595 \\
\hline PRTEE TOTAL-2 & $60.05 \pm 10.61$ & $58.1 \pm 10.34$ & 0.560 \\
\hline$p_{2}$ & $<0.001$ & $<0.001$ & - \\
\hline
\end{tabular}


+ exercise group at the $6^{\text {th }}$ and $12^{\text {th }}$ weeks of treatment in in a study of Yürük et al. (3) comparing the ESWT + exercise combination with placebo ESWT- exercise combination; but ESWT + exercise was not superior to the placebo group. In a randomized, multicentred, double-core, placebo-controlled study, Pettrone and McCall reported $50-61 \%$ increase of pain in the ESWT group at 1-year follow-up; and a 29\% improvement in the placebo group. They argued that ESWT was a safe and effective treatment for pain (33). Wang and Chen investigated the efficacy of low energy ESWT and placebo ESWT in LE. They found that palpation pain, muscle strength and functionality developed in the treatment group and no side effects were reported. In a randomized controlled trial with ESWT in 62 patients who were resistant to conservative treatments, Spacca et al. (25) reported a decrease in pain, grip strength and function during 6 months.

There is a decrease in pain with ESWT. The treatment of active MTrPs with DN method contributes to pain reduction. Therefore, increase in grip strength and improvement in daily functions are seen. In our study, pain, muscle strength and functionality scores improved in both groups, whereas ESWTDN combination was superior to ESWT group $(p<0.001)$ (Table 2, Table 3).

These results show us while treating tendinitis with ESWT; at the same time DN treatment of active MTrPs in the lateral epicondyl site both reduces the patient's pain and increases the awareness and adaptation of the patients' to the strengthening and stretching exercises which are indispensable for the treatment

\section{Study Limitations}

1. Low number of patients and the absence of long-term results of the ESWT-DN combination.

2. No comparative treatment with a sham control group.

3. DN therapy was applied without ultrasound and/or electrical stimulation.

\section{Conclusion}

In this study, we aimed to contribute to the literature by showing the effectiveness of ESWT and DN combination, which was performed for the first time in the treatment of LE. Both treatment methods are cost-effective and easy to apply. We think that additional studies should be done in this direction.

\section{Ethics}

Ethics Committee Approval: The approval of the Ethics Committee of the Kars Kafkas University Faculty of Medicine was obtained for our study (18/05/2018, LUT 10/12-13).

Informed Consent: All participants were informed about the study and their written informed consent was taken.

Peer-review: Internally peer-reviewed.

\section{Authorship Contributions}

Surgical and Medical Practices: F.B., Concept: F.B., Design: F.B., N.Y., Data Collection or Processing: F.B., Analysis or
Interpretation: F.B., N.Y., Literature Search: F.B., N.Y., Writing: F.B., N.Y.

Conflict of Interest: No conflict of interest was declared by the authors.

Financial Disclosure: The authors declared that this study received no financial support.

\section{References}

1. Valen PA, Foxworth J. Evidence supporting the use of physical modalities in the treatment of upper extremity musculoskeletal conditions. Curr Opin Rheumatol 2010;22:194-204.

2. Faro F, Wolf JM. Lateral epicondylitis: review and current concepts. J Hand Surg Am 2007;32:1271-9.

3. Yürük ZÖ, Kırdı N, Simşek N. Lateral epikondilitli olgularda radyal ekstrakorporeal şok dalga tedavisi ağrı, kavrama kuvveti ve fonksiyonellik üzerine etkisi: Randomize kontrollü çalıșma. 2016.

4. Keus SHJ, Smidt N, Assendelft WJJ. Treatment of lateral epicondylitis in general practice: result of a survey. Eur Gen Pract 2002;8:71-2.

5. Chard MD, Hazleman BL. Tennis elbow-a reappraisal. Br J Rheumatol 1989;28:186-90.

6. Waseem M, Nuhmani S, Ram CS, Sachin Y. Lateral epicondylitis: a review of the literature. J Back Musculoskelet Rehabil 2012;25:131-42.

7. Peterson $M$, Butler $S$, Eriksson $M$, Svärdsudd K. A randomized controlled trial of exercise versus wait-list in chronic tennis elbow (lateral epicondylosis). Ups J Med Sci 2011;116:269-79.

8. Sems A, Dimeff R, lannotti JP. Extracorporeal shock wave therapy in the treatment of chronic tendinopathies. J Am Acad Orthop Surg 2006;14:195-204.

9. Wang CJ. Extracorporeal shockwave therapy in musculoskeletal disorders. J Orthop Surg Res 2012;7:11.

10. Stenhouse G, Sookur P, Watson M. Do blood growth factors offer additional benefit in refractory lateral epicondylitis? A prospective, randomized pilot trial of dry needling as a stand-alone procedure versus dry needling and autologous conditioned plasma. Skeletal Radiol 2013:42:1515-20.

11. Uygur E, Aktaş B, Özkut A, Erinç S, Yilmazoglu EG. Dry needling in lateral epicondylitis: a prospective controlled study. Int Orthop 2017;41:2321-5.

12. Shah JP, Danoff JV, Desai MJ, Parikh S, Nakamura LY, Phillips TM, et al. Biochemicals associated with pain and inflammation are elevated in sites near to and remote from active myofascial trigger points. Arch Phys Med Rehabil 2008;89:16-23.

13. Hong CZ. Lidocaine injection versus dry needling to myofascial trigger point. The importance of the local twitch response. Am J Phys Med Rehabil 1994;73:256-63.

14. Fernández-Carnero J, Fernández-de-Las-Peñas $C$, de la LlaveRincón Al, Ge HY, Arendt-Nielsen L. Prevalence of and referred pain from myofascial trigger points in the forearm muscles in patients with lateral epicondylalgia. Clin J Pain 2007;23:353-60.

15. Walker-Bone K, Palmer KT, Reading I, Coggon D, Cooper C. Prevalence and impact of musculoskeletal disorders of the upper limb in the general population. Arthritis Rheum 2004;51:642-51.

16. Dorf ER, Chhabra AB, Golish SR, McGinty JL, Pannunzio ME. Effect of elbow position on grip strength in the evaluation of lateral epicondylitis. J Hand Surg Am 2007;32:882-6.

17. Altan L, Ercan I, Konur S. Reliability and validity of Turkish version of the patient rated tennis elbow evaluation. Rheumatol Int 2010;30:1049-54

18. Viswas R, Ramachandran R, Korde Anantkumar P. Comparison of Effectiveness of Supervised Exercise Program and Cyriax Physiotherapy in Patients with Tennis Elbow (Lateral Epicondylitis): A Randomized Clinical Trial. The Scientific World Journal. 2012.

19. Nirschl RP, Ashman ES. Tennis elbow tendinosis (epicondylitis). Instr Course Lect 2004;53:587-98.

20. Simons DG, Travell J, Simons LS. Travell and Simons' Myofascial Pain and Dysfunction: The Trigger Point Manual. Vol 1, 2nd ed. Baltimore: Williams \& Wilkins; 1999. 
21. Clinton RE, Murthi AM. Elbow: Lateral epicondylitis. Curr Orthop Pract 2008;19:612-5.

22. Marcolino AM, das Neves LM, Oliveira BG, Alexandre AA, Corsatto G, Barbosa RI, et al. Multimodal approach to rehabilitation of the patients with lateral epicondylosis: a case series. Springerplus 2016;5:1718.

23. Coombes BK, Bisset L, Vicenzino B. Management of Lateral Elbow Tendinopathy: One Size Does Not Fit All. J Orthop Sports Phys Ther 2015;45:938-49.

24. Herquelot E, Bodin J, Roquelaure Y, Ha C, Leclerc A, Goldberg M, et al. Work-related risk factors for lateral epicondylitis and other cause of elbow pain in the working population. Am J Ind Med 2013;56:400-9.

25. Spacca G, Necozione S, Cacchio A. Radial shock wave therapy for lateral epicondylitis: a prospective randomised controlled singleblind study. Eura Medicophys 2005;41:17-25.

26. Gerdesmeyer L, Frey C, Vester J, Maier M, Weil L Jr, Weil L Sr, et al. Radial extracorporeal shock wave therapy is safe and effective in the treatment of chronic recalcitrant plantar fasciitis: results of a confirmatory randomized placebo-controlled multicenter study. Am J Sports Med 2008;36:2100-9.
27. Chung B, Wiley P. Effectiveness of extracorporeal shock wave therapy in the treatment of previously untreated lateral epicondylitis: a randomized controlled trial. Am J Sports Med 2004;32:1660-7.

28. Shmushkevich Y, Kalichman L. Myofascial pain in lateral epicondylalgia: a review. J Bodyw Mov Ther 2013;17:434-9.

29. Fernández-Carnero J, Fernández-de-las-Peñas C, de la LlaveRincón Al, Ge HY, Arendt-Nielsen L. Bilateral myofascial trigger points in the forearm muscles in patients with chronic unilateral lateral epicondylalgia: a blinded, controlled study. Clin J Pain 2008;24:802-7.

30. Mishra A, Pavelko T. Treatment of chronic elbow tendinosis with buffered platelet-rich plasma. Am J Sports Med 2006:34:1774-8.

31. Ajimsha MS, Chithra S, Thulasyammal RP. Effectiveness of myofascial release in the management of lateral epicondylitis in computer professionals. Arch Phys Med Rehabil 2012;93:604-9.

32. Nourbakhsh MR, Fearon FJ. The effect of oscillating-energy manual therapy on lateral epicondylitis: a randomized, placebocontrol, double-blinded study. J Hand Ther 2008;21:4-13.

33. Pettrone FA, McCall BR. Extracorporeal shock wave therapy without local anesthesia for chronic lateral epicondylitis. J Bone Joint Surg Am 2005;87:1297-304. 